\title{
HUBUNGAN KESEHATAN MENTAL, MINAT BELAJAR, DAN KOMPETENSI MENGAJAR TERHADAP HASIL BELAJAR OLAHRAGA SENAM
}

\author{
Donny Setiawan ${ }^{1} *$, Ines Monica Soraya ${ }^{2}$ \\ ${ }^{1}$ Universitas PGRI Banyuwangi, Jawa Timur, Indonesia, 41482 \\ ${ }^{2}$ MAN 2 Banyuwangi, Jawa Timur, Indonesia, 68465 \\ *Coressponding Author: donnysetiawaneva@gmail.com
}

\section{Keterangan}

Rekam Jejak:

Received, Oktober 2020

Revised, November 2020

Accepted, Desember 2020

Kata Kunci:

Kesehatan Mental, Minat

Belajar, Kompetensi

Mengajar, Olahraga Senam
Tujuan penelitian ini untuk mengetahui beberapa hal, antara lain; (1) Ada tidaknya hubungan antara kesehatan mental dengan hasil belajar roll depan dan roll belakang siswa kelas X di MAN 2 Banyuwangi. (2) Ada tidaknya hubungan antara minat belajar dengan hasil belajar roll depan dan roll belakang siswa kelas X di MAN 2 Banyuwangi. (3) Ada tidaknya hubungan antara kompetensi mengajar guru pendidikan jasmani dengan hasil belajar roll depan dan roll belakang siswa kelas X di MAN 2 Banyuwangi. (4) Ada tidaknya hubungan antara kesehatan mental, minat belajar, dan kompetensi mengajar guru pendidikan jasmani dengan hasil belajar roll depan dan roll belakang siswa kelas X di MAN 2 Banyuwangi. Penelitian ini merupakan penelitian korelasional. Populasi dalam penelitian ini adalah siswa kelas X di MAN 2 Banyuwangi: 451 siswa. Pengambilan sampel menggunakan random sampling sebanyak 113 siswa. Teknik pengumpulan data menggunakan metode angket untuk variabel bebas kesehatan mental, minat belajar dan kompetensi mengajar guru, melakukan observasi untuk mengetahui variabel terikat hasil belajar roll depan dan roll belakang siswa. Teknik analisis data menggunakan analisis korelasi dan regresi ganda. Berdasarkan hasil penelitian dapat disimpulkan beberapa hal, antara lain; (1) Tidak ada hubungan antara kesehatan mental dengan hasil belajar roll depan dan roll belakang siswa kelas X di MAN 2 Banyuwangi. (2) Tidak ada hubungan antara minat belajar dengan hasil belajar roll depan dan roll belakang siswa kelas X di MAN 2 Banyuwangi. (3) Tidak ada hubungan antara kompetensi mengajar guru pendidikan jasmani dengan hasil belajar roll depan dan roll belakang siswa kelas X di MAN 2 Banyuwangi. (4) Tidak ada hubungan antara kesehatan mental, minat belajar dan kompetensi mengajar guru pendidikan jasmani dengan hasil belajar roll depan dan roll belakang siswa kelas X di MAN 2 Banyuwangi.

Copyright (C) 2020

Jurnal Olahraga \& Kesehatan Indonesia 


\section{PENDAHULUAN}

Dalam pendidikan dibutuhkan suatu proses pembelajaran yang baik. Pembelajaran sendiri merupakan suatu proses dimana ada interaksi antara guru dan siswa dimana guru memberikan suatu materi untuk dipahami siswa yang kemudian bisa meningkatkan kemampuan dan pengalaman siswa. Menurut Rini (2013:12) pembelajaran merupakan bantuan yang diberikaan pendidik agar terjadi proses perolehan ilmu dan pengetahuan, penguasaan kemahiran dan tabiat, serta pembentukan sikap dan kepercayaan pada peserta didik. Dalam proses pembelajaran diperlukan berbagai faktor pendukung agar proses pembelajaran bisa berjalan sesuai dengan tujuan sehingga bisa mencapai keberhasilan belajar siswa yang maksimal, beberapa faktor diantaranya yaitu kesehatan mental siswa, minat belajar siswa, dan kompetensi mengajar guru. Kesehatan mental merupakan kondisi seseorang yang mampu menyesuaikan diri dengan berbagai keadaan disekitarnya dengan rasa nyaman dan aman sehingga dalam menjalani kehidupannya seseorang tersebut tidak merasa terganggu ataupun tertekan dengan keadaan disekitarnya. Kesehatan mental dalam proses pembelajaran memiliki peran yang sangat penting karena dengan mental yang sehat siswa akan memiliki rasa nyaman dan tenang sehingga bisa meningkatkan konsentrasi belajar dalam melaksanakan pembelajaran.

Dalam proses pembelajaran juga dibutuhkan minat belajar yang tinggi. Minat belajar terdiri dari dua kata yaitu minat dan belajar. Minat adalah keadaan dimana seseorang mempunyai rasa suka untuk melakukan aktivitas yang digemarinya sehingga memiliki ketertarikan khusus untuk mempelajari sesuatu lebih mendalam. Belajar merupakan suatu proses dimana seseorang memperoleh berbagai ilmu pengetahuan maupun pengalaman dari lingkungan sekitar yang bertujuan agar terjadi perubahan dalam dirinya sebagai bekal kehidupannya. Oleh karena itu minat belajar sangat mempengaruhi suatu proses pembelajaran, karena dengan minat belajar yang tinggi maka rasa senang dan rasa ingin tahu siswa terhadap suatu pelajaran akan meningkat yang pada akhirnya siswa mempunyai keinginan untuk terus mempelajari pelajaran tersebut hingga mendapatkan hasil yang maksimal. Untuk melaksanakan proses belajar pendidikan jasmani diperlukan guru yang profesional dan berkulitas. Guru adalah seseorang yang memberikan ilmu kepada siswanya melalui proses pembelajaran, sebagai pendidik guru merupakan salah satu faktor penentu keberhasilan setiap upaya yang dilakukan dalam pendidikan, oleh karena itu kompetensi guru yang baik dalam mengajar sangat diperlukan guna mencapai keberhasilan pembelajaran. Kompetensi dalam pengertian umum biasanya menyatu pada kemampuan atau keterampilan yang dimiliki individu atau kelompok bahkan lembaga. Kata kompetensi ditinjau dari persepektif etimologi berasal dari kata "competence" atau mampu.

Pada kenyataannya proses pembelajaran pendidikan jasmani di sekolah masih ada berbagai kendala seperti analisis yang dilaksanakan peneliti di salah satu Madrasah Aliyah Negeri Kabupaten Banyuwangi yaitu MAN 2 Banyuwangi. Dalam proses pembelajaran didalam kelas khusunya pembelajaran pendidikan jasmani masih ada beberapa siswa yang enggan memperhatikan gurunya saat menyampaikan materi seolah-olah bukan hal penting untuk mengetahui materi pendidikan jasmani karena sebagian besar siswa berfikir pendidikan jasmani adalah materi praktek olahraga yang dilkasanakan dilapangan, namun ketika dilapangan saat melakukan aktivitas olahraga tidak sedikit siswa yang masih bermalas-malasan dan tidak melakukan gerakan olahraga secara benar, sehingga hasil yang didapat setelah proses pembelajaran tidak maksimal. Selain dari analisis, peneliti juga melakukan observasi terkait hasil belajar roll depan dan roll belakang siswa yang dilakukan melalui wawancara pada guru pendidikan jasmani di MAN 2 Banyuwangi, hasil dari observasi tersebut yaitu hasil belajar roll depan dan roll belakang untuk siswa putra sudah memenuhi kkm sedangkan untuk siswa putri sebagian besar masih belum memenuhi kkm, di MAN 2 Banyuwangi siswa putri lebih dominan daripada siswa putra oleh karena itu peneliti mengambil kesimpulan bahwa sebagian besar siswa masih belum memenuhi kkm yang sudah ditetapkan di Madrasah. 


\section{METODE}

Penelitian ini merupakan penelitian korelasional dengan tiga variabel bebas yaitu kesehatan mental, minat belajar dan kompetensi mengajar guru dan satu variabel terikat yaitu hasil belajar. Menurut Winarno (2013) penelitian korelasional hanya mampu mengungkapkan kekuatan hubungan antar variabel, yang ditandai oleh koefisien korelasi. Artinya, hanya mampu mengungkapkan bentuk hubungan (positif atau negatif) dengan indeks diterminasi, dan tidak mengungkapakan saling hubungan yang bersifat kausal seperti dalam penelitian kausal komparatif dan eksperimental. Metode yang digunakan dalam penelitian ini yaitu metode angket. Penelitian ini memiliki tujuan untuk mengetahui apakah ada hubungan antara kesehatan mental, minat belajar dan kompetensi mengajar guru pendidikan jasmani dengan hasil belajar roll depan dan roll belakang siswa kelas X di MAN 2 Banyuwangi. Desain penelitian dapat digambarkan dengan bagan di bawah ini:

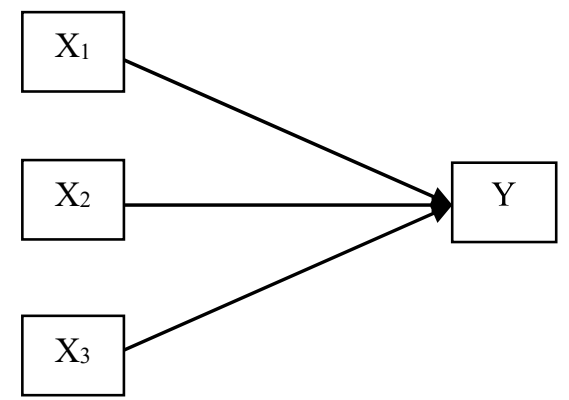

Gambar 1. Desain Penelitian

Keterangan:

$\mathrm{X}_{1} \quad=$ Kesehatan Mental Siswa

$\mathrm{X}_{2} \quad=$ Minat Belajar Siswa

$\mathrm{X}_{3} \quad=$ Kompetensi Mengajar Guru

$\mathrm{Y} \quad=$ Hasil Belajar Roll Depan dan Roll Belakang Senam Lantai

Populasi dalam penelitian ini adalah seluruh siswa kelas X di MAN 2 Banyuwangi yang terdiri dari 12 kelas dengan jumlah total 451 siswa dan guru kelas X di MAN 2 Banyuwangi. Prosedur penelitian merupakan langkah-langkah yang harus dilalui oleh peneliti dalam menerapkan metode penelitian yang akan digunakan. Untuk memperoleh hasil penelitianyang diharapkan, prosedur penelitian dalan penilitian ini meliputi tahap-tahap sebagai berikut: Tahap pesiapan survey awal, Penentuan sampel dan metode penelitian, Penyiapan instrument, Tahap pengumpulan data dan tindakan. Dalam penelitian ini untuk menganalisis hubungan antara kesehatan mental, minat belajar dan kompetensi mengajar guru secara terpisah dengan hasil belajar pendidikan jasmani digunakan teknik korelasi product moment dari Pearson. Sedangkan untuk mengetahui hubungan antara kesehatan mental, minat belajar dan kompetensi mengajar guru secara bersama-sama dengan hasil belajar pendidikan jasmani digunakan uji regresi linier ganda.

\section{HASIL \& PEMBAHASAN}

Hasil

Penelitian ini dimaksudkan untuk mengetahui: (1) Ada tidaknya hubungan antara kesehatan mental dengan hasil belajar roll depan dan roll belakang siswa kelas X di MAN 2 Banyuwangi. (2) Ada tidaknya hubungan antara minat belajar dengan hasil belajar roll depan dan roll belakang siswa kelas X di MAN 2 Banyuwangi. (3) Ada tidaknya hubungan antara kompetensi mengajar guru pendidikan jasmani dengan hasil belajar roll depan dan roll belakang siswa kelas X di MAN 2 Banyuwangi. (4) Ada tidaknya hubungan antara kesehatan mental, 
minat belajar, dan kompetensi mengajar guru pendidikan jasmani dengan hasil belajar roll depan dan roll belakang siswa kelas X di MAN 2 Banyuwangi.

Data yang diperoleh untuk mengetahui kesehatan mental, minat belajar dan kompetensi mengajar guru pendidikan jasmani dengan instrumen penelitian berupa angket yang disampaikan kepada sample penelitian sejumlah 113 siswa, selain menggunakan angket data penelitian ini juga diperoleh dari observasi untuk mengetahui hasil belajar roll depan dan roll belakang siswa kelas X di MAN 2 Banyuwangi. Dalam penelitian ini terdiri tiga variabel bebas dan satu variabel terikat. Variabel bebas pertama adalah kesehatan mental, variabel bebas kedua adalah minat belajar, dan variabel bebas ketiga adalah kompetensi mengajar guru pendidikan jasmani. Sedangkan variabel terikatnya adalah hasil belajar roll depan dan roll belakang siswa. Deskripsi data dalam penelitian ini peneliti sajikan sebagai berikut:

- Kesehatan mental $\left(\mathrm{X}_{1}\right)$

Data tentang kesehatan mental dari instrumen angket dapat disajikan dimana jumlah responden $(\mathrm{N})=113$ siswa, skor tertingi $=112$, skor terendah $=76$, mean $=95,31$.

- Minat belajar $\left(\mathrm{X}_{2}\right)$

Data tentang minat belajar diperoleh menggunakan instrumen angket. Adapun hasil penyebaran angket kepada responden diperoleh data dimana jumlah responden $(\mathrm{N})=113$ siswa, skor tertinggi $=110$, skor terendah $=70$, mean $=88,17$.

- Kompetensi mengajar $\left(\mathrm{X}_{3}\right)$

Data tentang kompetensi mengajar guru diperoleh menggunakan instrumen angket yang disebar kepada responden dan diperoleh data dimana jumlah responden $(\mathrm{N})=113$ siswa, skor tertinggi $=42$, skor terendah $=22$, mean $=29,58$.

- Hasil belajar roll depan dan roll belakang siswa (Y)

Data tentang hasil belajar roll depan dan roll belakang siswa diperoleh dengan menggunakan instrumen angket yang disebar kepada responden dan diperoleh data dimana jumlah responden $(N)=113$ siswa, skor tertinggi $=87$, skor terendah $=55$, mean $=69,32$.

Tabel 1. Ringkasan Deskripsi Data

\begin{tabular}{ccccc}
\hline Variabel & N & Maximum & Minimum & Mean \\
Kesehatan Mental Siswa (X1) & 113 & 112 & 76 & 95,31 \\
Minat Belajar Siswa (X2) & 113 & 110 & 70 & 88,17 \\
Kompetensi Mengajar Guru (X3) & 113 & 42 & 22 & 29,58 \\
Hasil Belajar Senam Lantai (Y) & 113 & 87 & 55 & 69,32 \\
\hline
\end{tabular}

\section{Pembahasan}

Pengujian hipotesis dimaksudkan untuk mengetahui apakah hipotesis yang dirumuskan dapat teruji kebenarannya atau tidak. Sesuai dengan tujuan penelitian maka untuk pengujian hipotesis dalam penelitian ini menggunakan teknik korelasi product moment dan uji regresi ganda, yang dijabarkan sebagai berikut:

Hubungan antara $\left(\mathrm{X}_{1}\right)$ dengan $(\mathrm{Y})$

Untuk menguji hipotesis yang menyatakan ada hubungan antara kesehatan mental dengan hasil belajar roll depan dan roll belakang siswa kelas X di MAN 2 Banyuwangi digunakan teknik analisis korelasi product moment. Berdasarkan hasil penghitungan analisis korelasi diperoleh $r_{\text {hitung }}=-0,074$. Hasil perhitungan kemudian dikonsultasikan dengan $r_{\text {tabel }}$ dengan taraf signifikansi $(\alpha)=0,05$, dengan d. $f=113$ diperoleh $r_{\text {tabel }}=0,176$ dan ternyata $r_{\text {hitung }}<r_{\text {tabel }}$ yaitu $-0,074<0,176$.

Dari analisis tersebut dapat disimpulkan bahwa hipotesis yang menyatakan ada hubungan antara kesehatan mental dengan hasil belajar roll depan dan roll belakang siswa kelas X di MAN 2 Banyuwangi belum terbukti kebenarannya atau Ha ditolak, sedangkan hipotesis yang 
menyatakan tidak ada hubungan antara kesehatan mental dengan hasil belajar roll depan dan roll belakang siswa kelas X di MAN 2 Banyuwangi terbukti kebenarannya atau Ho diterima.

Hubungan antara $\left(\mathrm{X}_{2}\right)$ dengan $(\mathrm{Y})$

Untuk menguji hipotesis yang menyatakan ada hubungan antara minat belajar dengan hasil belajar roll depan dan roll belakang siswa kelas X di MAN 2 Banyuwangi digunakan teknik analisis korelasi product moment. Berdasarkan hasil penghitungan analisis korelasi diperoleh $r_{\text {hitung }}=-0,092$. Hasil perhitungan kemudian dikonsultasikan dengan $r_{\text {tabel }}$ dengan taraf signifikansi $(\alpha)=0,05$, dengan d. $f=113$ diperoleh $r_{\text {tabel }}=0,176$ dan ternyata $r_{\text {hitung }}<r_{\text {tabel }}$ yaitu $-0,092<0,176$.

Dari analisis tersebut dapat disimpulkan bahwa hipotesis yang menyatakan ada hubungan antara minat belajar dengan hasil belajar roll depan dan roll belakang siswa kelas X di MAN 2 Banyuwangi belum terbukti kebenarannya atau Ha ditolak, sedangkan hipotesis yang menyatakan tidak ada hubungan antara minat belajar dengan hasil belajar roll depan dan roll belakang siswa kelas X di MAN 2 Banyuwangi terbukti kebenarannya atau Ho diterima.

Hubungan antara $\left(\mathrm{X}_{3}\right)$ dengan $(\mathrm{Y})$.

Untuk menguji hipotesis yang menyatakan ada hubungan antara kompetensi mengajar guru pendidikan jasmani dengan hasil belajar roll depan dan roll belakang siswa kelas X di MAN 2 Banyuwangi digunakan teknik analisis korelasi product moment. Berdasarkan hasil penghitungan analisis korelasi diperoleh $r$ hitung $=-0,235$. Hasil perhitungan kemudian dikonsultasikan dengan $r$ tabel dengan taraf signifikansi $(\alpha)=0,05$, dengan d.f $=113$ diperoleh $r$ tabel $=0,176$ dan ternyata $r_{\text {hitung }}<r_{\text {tabel }}$ yaitu $-0,235<0,176$.

Dari analisis tersebut dapat disimpulkan bahwa hipotesis yang menyatakan ada hubungan antara kompetensi mengajar guru pendidikan jasmani dengan hasil belajar roll depan dan roll belakang siswa kelas X di MAN 2 Banyuwangi belum terbukti kebenarannya atau Ha ditolak, sedangkan hipotesis yang menyatakan tidak ada hubungan antara kompetensi mengajar guru pendidikan jasmani dengan hasil belajar roll depan dan roll belakang siswa kelas X di MAN 2 Banyuwangi terbukti kebenarannya atau Ho diterima.

Hubungan antara $\left(\mathrm{X}_{1}\right),\left(\mathrm{X}_{2}\right)$, dan $\left(\mathrm{X}_{3}\right)$ dengan $(\mathrm{Y})$

Untuk menguji hipotesis yang menyatakan ada hubungan antara kesehatan mental, minat belajar dan kompetensi mengajar guru pendidikan jasmani bersama-sama dengan hasil belajar roll depan dan roll belakang siswa kelas X di MAN 2 Banyuwangi digunakan teknik analisis regresi dan korelasi ganda. Berdasarkan hasil penghitungan diperoleh $F_{\text {hitung }}=0,005$. Hasil perhitungan kemudian dikonsultasikan dengan $\mathrm{F}_{\text {tabel }}$ dengan taraf kesalahan 5\% didasarkan pada $\mathrm{dk}$ pembilang $=3$ dan dk penyebut $(113-3-1)=109$ diperoleh $\mathrm{F}_{\text {tabel }}=2,68$ dan ternyata $\mathrm{F}_{\text {hitung }}<$ $\mathrm{F}_{\text {tabel }}$ yaitu $0,005<2,68$ dengan taraf signifikansi $(\alpha)=0,05$.

Dari hasil penelitian menunjukkan tidak ada hubungan yang signifikan antara kesehatan mental dengan hasil belajar roll depan dan roll belakang siswa hal ini dibuktikan dengan hasil penghitungan analisis korelasi diperoleh $\mathrm{r}_{\text {hitung }}<\mathrm{r}_{\text {tabel }}$ yaitu $-0,074<0,176$. Tidak ada hubungan yang signifikan antara minat belajar dengan hasil belajar roll depan dan roll belakang siswa yang dibuktikan dengan hasil penghitungan analisis korelasi diperoleh $r$ hitung $<r$ tabel yaitu $-0,092$ $<0,176$. Tidak ada hubungan yang signifikan antara kompetensi mengajar guru pendidikan jasmani dengan hasil belajar roll depan dan roll belakang siswa dibuktikan dengan hasil penghitungan analisis korelasi diperoleh $\mathrm{r}_{\text {hitung }}<\mathrm{r}_{\text {tabel }}$ yaitu $-0,235<0,176$. Tidak ada hubungan yang signifikan antara kesehatan mental, minat belajar dan kompetensi mengajar guru dengan hasil belajar roll depan dan roll belakang siswa dibuktikan dengan hasil perhitungan analisis regresi dan korelasi ganda diperoleh $\mathrm{F}_{\text {hitung }}<\mathrm{F}_{\text {tabel }}$ yaitu $0,005<2,68$.

Dari beberapa hasil diatas semua Ha ditolak dan Ho diterima karena berdasarkan data yang diperoleh peneliti siswa mempunyai kesehatan mental yang baik, dan sebagian besar minat belajar siswa terhadap pelajaran pendidikan jasmani juga bisa dikatakan cukup tinggi, untuk kompetensi mengajar guru pendidikan jasmani juga bisa dikatakan baik, namun untuk hasil belajar roll depan dan roll belakang sebagian besar 
siswa masih dibawah rata-rata karena dari analisis peneliti ketika siswa melakukan roll depan dan roll belakang usaha yang dilakukan masih kurang seperti contoh ketika siswa melakukan roll belakang tidak bisa melakukan gerakan berguling kebelakang maka tidak ada usaha lagi agar bisa melakukan gerakan tersebut, dikuatkan lagi dengan data yang diperoleh peneliti sebagian besar siswa mendapatkan nilai belum tuntas.

\section{SIMPULAN}

Berdasarkan hasil penelitian dan pembahasan skripsi yang telah dilakukan, maka dapat ditarik kesimpulan sebagai berikut: (1) Tidak ada hubungan yang signifikan antara kesehatan mental dengan hasil belajar roll depan dan roll belakang siswa kelas $\mathrm{X}$ di MAN 2 Banyuwangi. (2) Tidak ada hubungan yang signifikan antara minat belajar dengan hasil belajar roll depan dan roll belakang siswa kelas X di MAN 2 Banyuwangi. (3) Tidak ada hubungan yang signifikan antara kompetensi mengajar guru pendidikan jasmani dengan hasil belajar roll depan dan roll belakang siswa kelas X di MAN 2 Banyuwangi. (4) Tidak ada hubungan yang signifikan antara kesehatan mental, minat belajar dan kompetensi mengajar guru pendidikan jasmani dengan hasil belajar roll depan dan roll belakang siswa kelas X di MAN 2 Banyuwangi. Tidak adanya hubungan yang signifikan antara kesehatan mental, minat belajar dan kompetensi mengajar guru pendidikan jasmani dengan hasil belajar roll depan dan roll belakang siswa kelas X di MAN 2 Banyuwangi disebabkan kurangnya usaha siswa untuk mendapatkan hasil yang baik saat proses pembelajaran.

\section{DAFTAR PUSTAKA}

Alfarisi, IA. (2015).Upaya Meningkatkan Hasil Belajar Headstand Melalui Metode Kartu Tugas pada kelas XI IPA SMAN 1 Sukorejo Kabupaten Kendal Tahun Pelajaran 2014/2015 [Skripsi]. Semarang: Universitas Negeri Semarang.

Anggaraini, ND, ME, Winarno, \& Sulistyorini. (2014). Pengembangan Pembelajaran Teknik Dasar Service Bawah Bolavoli untuk Siswa Kelas VIII SMP Negeri 5 Malang. 1(1): 81-87.

Aruansah, Ali, Saifuddin, \& Ifwandi. (2017). Kendala Siswi MAN Darussalam dalam Mengikuti Pembelajaran Pendidikan jasmaniorkes Tahun Ajaran 2016/2017. 3(2):92-104.

Djaali. (2018). Psikologi pendidikan. Jakarta: Bumi Aksara.

Firmansyah, Helmi. (2009). Hubungan Motivasi Berprestasi Siswa dengan Hasil Belajar Pendidikan Jasmani. 6(1): 30-33.

Fitriani, NA. (2013). Kompetensi Mengajar gur Pendidikan Jasmani Olahraga dan Kesehatan yang Bersertifikat Pendidik di SMP Kota Yogyakarta [Sripsi]. Yogyakarta: Universitas Negeri Yogyakarta.

Hadi, Rubianto. (2011). Peran Pelatih dalam Membentuk Kaarakter Atlet. 1(1)

Hamid, Abdul. (2017).Agama dan Kesehatan Mental dalam Persepektif Psikologi Agama. 3(1): $1-84$.

Handoko, Tri. (2016). Kreativitas Guru Pendidikan Jasmani Olahraga dan Kesehatan dalam Menyikapi Keterbatasan sarana dan Prasarana Pendidikan jasmani di Madrasah Aliyah Se-Kabupaten Magelang [Skripsi]. Yogyakarta : Universitas Negeri Yogyakarta.

LN., Syamsu Yusuf. (2018). Kesehatan Mental Persepektif Psikologis dan Agama. Bandung: PT Remaja Rosdakarya.

Peraturan Menteri Pendidikan Nasioanl Republik Indonesia Nomor 16 Tahun 2007 tentang Standar Kualifikasi Akademik dan Kompetensi Guru.

Peraturan Menteri Pendidikan Nasional Nomor 22 Tahun 2006 Tentang Standar Isi Untuk Satuan Pendidikan Dasar dan Menengah. 
PP Nomor 19 Tahun 2005 Tentang Standar Nasional Pendidikan.

Rini, PS. (2013). Pendekatan Media Audio Visual Senam Lantai Roll Depan dan Roll Belakang Untuk Meningkatkan Hasil Belajar dalam Pendidikan jasmaniorkes Siswa kelas VII di SMP Negeri 2 Kota Semarang Tahun 2012/2013 [Skripsi]. Semarang: Universitas Negeri Semarang.

Rohmansyah, NA. Setiyawan. (2018). Manajemen Pengembangan Kompetensi Profesional Guru Pendidikan Jasmani Sekolah Menengah Atas (SMA) Negeri di Kota Yogyakarta. 1(1): 47-54.

Saputra, KY. (2015). Pengaruh Proses Pembelajaran dan Motivasi Belajar Terhadap Hasil Belajar IPS Siswa SMP Maulana Pegayaman. 5(1).

Slameto. (2015). Belajar dan Faktor-Faktor yang Mempengaruhi. Jakarta: Rineka Cipta.

Sugiyono. (2018). Metode Penelitian Kuantitatif, Kualitatif, dan R\&D. Bandung: Alfabeta.

Sulistiyono, Fery. (2014). Peningkatan Minat Belajar Siswa Terhadap Pembelajaran Tematik Kelas I Melalui Metode Story Telling di SDN Gembongan Sentolo Kulon Progo [Skripsi]. Yogyakarta: Universitas Negeri Yosgyakarta.

Sulistiyorini, dan Muhammad Fathurrohman. (2012). Belajar dan Pembelajaran Meningkatkan Mutu Pembelajaran Sesuai Standar Nasional. Yogyakarta: Teras.

Sunaryo, Septianingrum. (2016). Minat Siswa dalam Mengikuti Pembelajaran Pendidikan Jasmani di SMP Negeri 2 Tempel Kab. Sleman Daerah Istimewa Yogyakarta [Skripsi]. Yogyakarta: Universitas Negeri Yogyakarta.

Suranto. (2009). Hubungan antara kesehatan mental dan motivasi belajar dengan kedisiplinan siswa kelas xi sma negeri di Kecamatan Purbalingga Kabupaten Purbalingga Tahun pelajaran 2008/2009 [Tesis]. Surakarta: Universitas Sebelas Maret.

Winarno, ME. (2013). Metode Penelitian dalam Pendidikan Jasmani. Malang: Universita Negeri Malang (UM PRESS).

Zuharon, Yahya. (2017). Kemampuan Guru pendidikan jasmani dalam Proses Pembelajaran Pendidikan jasmani Sekolah Dasar Negeri Se-Kecamatan Ngemplak Kabupaten Sleman [Skripsi]. Yogyakarta: Universitas Negeri Yogyakarta. 